\title{
Efficiency of Aluminum and Iron Electrodes for the Removal of Heavy Metals [(Ni (II), Pb (II), Cd (II)] by Electrocoagulation Method
}

\author{
Muhammad Kaleem Khosa*, Muhammad Asghar Jamal, Amira Hussain, \\ Majid Muneer, Khalid Mahmood Zia ${ }^{\dagger}$, and Samia Hafeez \\ Department of Chemistry, Government College University, Faisalabad 38000, Pakistan. \\ *E-mail: mkhosapk@yahoo.com \\ ${ }^{\dagger}$ Department of Applied Chemistry, Government College University, Faisalabad 38000, Pakistan \\ Department of Chemistry, Bahaud-din-Zakariya University, Multan, 60800, Pakistan.
}

(Received February 12, 2013; Accepted April 13, 2013)

\begin{abstract}
Electrocoagulation (EC) technique is applied for the treatment of wastewater containing heavy metals ions such as nickle $(\mathrm{Ni})$, lead $(\mathrm{Pb})$ and cadmium $(\mathrm{Cd})$ by using sacrificial anodes corrode to release active coagulant flocs usually aluminium or iron cations into the solution. During electrolytic reactions hydrogen gas evolve at the cathode. All the experiments were carried out in Batch mode. The tank was filled with synthetic wastewater containing heavy metals and efficiency of electrocoagulation in combination with aluminum and iron electrodes were investigated for removal of such metals. Several parameters, such as contact time, $\mathrm{pH}$, electro-coagulant concentration, and current density were optimized to achieve maximum removal efficiency (\%). The concentrations of heavy metals were determined by using Atomic Absorption Spectroscopy (AAS). It is found that the electro-coagulation process has potential to be utilized for the cost-effective removal of heavy metals from wastewater specially using iron electrodes in terms of high removal efficiencies and operating cost.
\end{abstract}

Key words: Aluminum electrode, Iron electrode, Industrial wastewater, Heavy metals, Electrocoagulation

\section{INTRODUCTION}

Heavy metals are toxic in nature and these metals are released directly into the environment from a number of point sources and non-point sources such as electro-plating, metal processing, mining, dyeing and automobile manufacturing industries. High toxicity and non-biodegradability of heavy metals, such as copper, lead, chromium, cadmium, zinc and nickel, caused a number of environmental problems. For most countries, the concentration of toxic heavy metals in effluents should be controlled in order to meet the water quality standards. ${ }^{1}$ Different separation techniques for the treatment of industrial wastewater containing heavy metals include adsorption, filtration, precipitation, electrodialysis, reverse osmosis, solvent extraction and ion exchange are used but due to their selective separation efficiencies have limitations and they are also not cost effective techniques. ${ }^{2}$ In UK in 1889 , it was first proposed to use the electricity to treat wastewater. The process of electrocoagulation was first applied to drinking water on large scale in the US in $1946 .{ }^{3}$ Short wave electrolysis or radio Frequency Diathermy is the other names of electrocoagulation (EC). Different physical and biological processes are used for the treatment wastewater; these include electrooxidation (EO), electrocoagulation (EC) and electroflotation (EF). ${ }^{4}$ Electrocoag- ulation (EC) is becoming a popular process for the treatment of wastewater due to some advantages over chemical coagulation can be applied to a broad range of water and wastewater treatment systems and are most effective in removing inorganic contaminants and pathogens. Because of their broad applicability, they have been used for groundwater and surface water remediation at several sites. A combined process of electrocoagulation and electroflotation in a continuous flow reactor was used to treat wastewater from restaurants in Hong Kong with high oil and grease content. ${ }^{5}$ Several reports have been published in scientific journals on electrocoagulation combined with electroflotation for treating potablewater, ${ }^{6-14}$ decolourisation of a strongly coloured solution containing reactive textile dyes. ${ }^{15-19}$

In France an electrocoagulation and flotation system was joined to study the membrane process (microfiltration) on the flux of municipal wastewater treatment. ${ }^{20,21}$ The research studies showed that electrocoagulation is an efficient technology for treatment of industrial wastewaters. However, the capacity and efficiency of an electrocoagulation process depends on the nature of the effluents and initial pollutant concentrations. By electrocoagulation method suspended solids, hydrocarbons and heavy metals can be removed from wastewater by destabilization of finally dispersed particles. ${ }^{22}$ Aluminium or Iron electrodes are usually used as 
sacrificial electrodes and by applying direct current; cations are generated by dissolution of sacrificial anodes and reacted with hydroxyl ions in the solution and hydrogen gas is produced at the cathode. ${ }^{23}$

The metal hydroxide ions are produced by the hydrolysis of metal ions generated in the electrochemical cell according to reactions $1-6$ and at $\mathrm{pH}$ in range of 6.0-7.0, the only neutral specie $\mathrm{M}(\mathrm{OH})_{3}$ has a very low solubility. When metal species react with negatively charged particles flocs are generated in the water. The coagulants are generated in situ so no addition of any chemicals is required in electrocoagulation process. The production of gases during the electrolysis of water and dissolution of metal permit the resulting flocs to floated. ${ }^{24}$

$$
\begin{aligned}
& \mathrm{Al} \rightarrow \mathrm{Al}^{3+}{ }_{(\mathrm{aq})}+3 \mathrm{e}^{-} \\
& 3 \mathrm{H}_{2} \mathrm{O}+3 \mathrm{e}^{-} \rightarrow 3 / 2 \mathrm{H}_{2(\mathrm{~g})}+3 \mathrm{OH}^{-} \\
& \mathrm{Al}^{3+}{ }_{(\mathrm{aq})}+3 \mathrm{H}_{2} \mathrm{O} \rightarrow \mathrm{Al}(\mathrm{OH})_{3}+3 \mathrm{H}^{+}
\end{aligned}
$$

The floc of aluminum hydroxide mainly act as adsorbent for the metal ions. Therefore it can eliminate them from solution.

And for the iron electrodes

$$
\begin{aligned}
& 3 \mathrm{H}_{2} \mathrm{O}+\mathrm{e}^{-} \rightarrow 3 / 2 \mathrm{H}_{2(\mathrm{~g})}+3 \mathrm{OH}^{-} \\
& 4 \mathrm{Fe}_{(\mathrm{s})} \rightarrow 4 \mathrm{Fe}^{2+}+8 \mathrm{e}^{-} \\
& 4 \mathrm{Fe}_{(\mathrm{s})}+10 \mathrm{H}_{2} \mathrm{O}_{(\mathrm{l})}+\mathrm{O}_{2(\mathrm{~g})} \rightarrow 4 \mathrm{Fe}(\mathrm{OH})_{3(\mathrm{~s})}+4 \mathrm{H}_{2(\mathrm{~g})}
\end{aligned}
$$

The main aim of this investigation is to present bench and field scale research studies for the EC and ECF technology to remove different pollutants from water and wastewater treatment plants. These processes are characterized by ease of operation, reduced production of sludge, and no need to handle chemicals. They have been applied efficiently to various water treatment problems. Therefore, if EC can replace conventional chemical coagulation, very little modification is required to make the present treatment plants more efficient and resolve the many problems caused by chemical coagulation.

\section{MATERIALS AND METHODS}

Self Synthetic wastewater samples were prepared in the laboratory. Different concentrations were prepared by dissolving appropriate amount of salts of $\mathrm{Ni}$ (II), $\mathrm{Cd}$ (II) and $\mathrm{Pb}$ (II) in distilled water.

\section{EXPERIMENTAL SETUP}

The experimental setup is shown in Fig. 1 which was used for the study of electrocoagulation consist of electro-

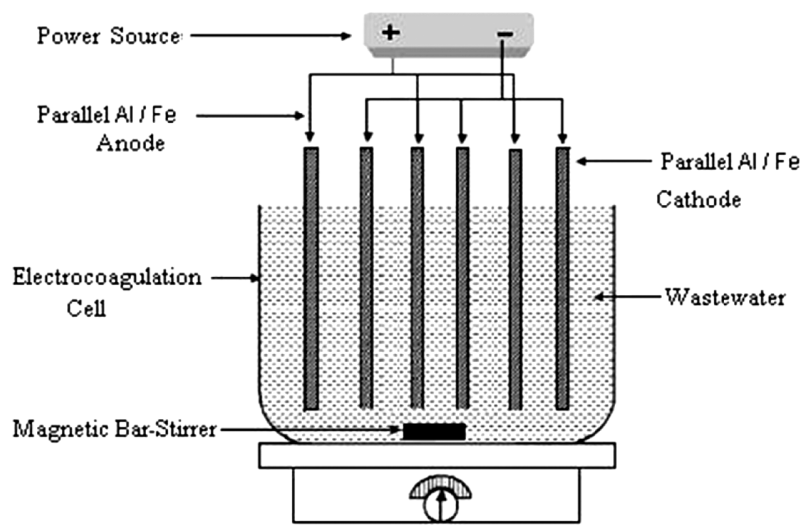

Figure 1. A schematic diagram of experimental setup.

lytic cell of 1.5 liter, having effective volume of $1000 \mathrm{~cm}^{3}$ to hold the sample. Baffles were attached to the inner phase of electrolytic cell which further facilitated the proper mixing of sample and created a turbulent flow. Three pairs of iron / aluminum electrodes were used separately that have an active surface area of $16 \mathrm{~cm}^{2}$, serve as cathode and anode. These electrodes were arranged having space of $2.5 \mathrm{~cm}$ between them. Electrodes were connected to DC power source and to minimize the mass transfer during the course of reaction, a magnetic stirrer was used which facilitated the proper mixing of solution. A switch was used to change the polarity of electrodes which reduced the passivation phenomenon. Passivation phenomenon further disturbed oxidation and reduction processes during the course of reaction. ${ }^{25}$

\section{EXPERIMENTAL PROCEDURE}

All the experiments were conducted in a bipolar batch reactor. A set of 6 aluminum electrodes or 6 iron electrodes were used respectively that was connected in parallel. A synthetic wastewater sample was prepared in each experimental run and then placed in an electrolytic cell. Potassium chloride $(1 \mathrm{~N})$ was added to increase the conductivity of solution by reducing the phenomenon of passivation which occurred due to formation of oxide layer on anode. Aluminum and iron electrodes were dipped into the sample solution so that they had maximum surface area in sample solution. Proper mixing of solution was achieved by a magnetic stirrer while $\mathrm{pH}$ of the solution was adjusted by $1 \mathrm{M}$. sodium hydroxide / 1 M. sulphuric acid solution. At the end of each experiment, the mass loss of aluminum and iron electrodes were measured respectively. The current of 1.0 to 5.0 A were passed for contact time of $0,2,4,6,8,10$ minutes. Samples were extracted after every $10 \mathrm{~min}$ and after filtration of the solution through $0.45-\mu \mathrm{m}$ mixed cellulose 
acetate membrane, $\mathrm{pH}$ and conductance were measured by transferring solution into another beaker. The residual metal ions concentration was determined according to the standard method by using the Atomic Absorption method. ${ }^{26}$ The amount of metal ions removal was measured at $\mathrm{pH} 1,2$, $3,5,7$ and 9 and in electrical potential of 5, 9, and $12 \mathrm{~V}$.

\section{RESULTS AND DISCUSSION}

The process of electrocoagulation is not so complex and can be examined by the optimization of several parameters like contact time, initial $\mathrm{pH}$, electrocoagulant concentration and current density. In the present study, the process of electrocoagulation has been explored as a treatment technology for the removal of nickel, lead and cadmium from synthetic wastewater. After electrocoagulation process it was observed that the conductance values of the water samples were in permissible range. While color of the wastewater samples disappears as the contact time increased. Removal efficiency of these metal ions in different operating conditions such as $\mathrm{pH}$, electro-coagulant concentration and current density at various intervals of time has been evaluated. After the treatment of wastewater by electrocoagulation process, the percent removal efficiency (RE\%) calculated by following formula:

$$
\mathrm{RE} \%=\left(\mathrm{C}_{0}-\mathrm{C} / \mathrm{C}_{0}\right) \times 100
$$

Where

$\mathrm{C}_{0}=$ Initial pollutant ions concentration

$\mathrm{C}=$ Final pollutant ions concentration

The mass of aluminum and iron electrodes decreased as the time of electrolysis increased. There is more consumption of mass in acidic media.

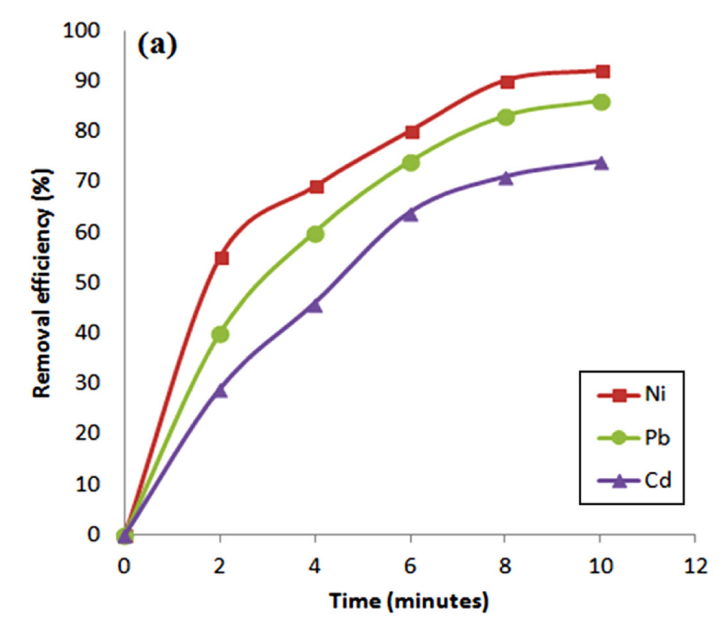

\section{Effect of Contact Time}

The effect of operating time on the removal of nickel, lead and cadmium by process of electrocoagulation is shown in Fig. 2( $\mathrm{a}$ and b). The maximum removal efficiency of nickel, lead and cadmium is 92,86 and $74 \%$ respectively for aluminium electrodes. Similarly, the maximum removal efficiency for nickel is $99 \%$ while that of lead and cadmium is 90 and $89 \%$ respectively with same reaction time using iron electrodes. It was observed that a successive decreased in the initial metal ions concentration caused by increasing reaction time. The electrocoagulation efficiency for removing heavy metals from wastewater is high by using iron electrodes because there is the less consumption of electrode mass for the efficient removal of metal as the metal concentration in the solution increased. Due to excess amount of floc formation which ultimately sweeps away the metal from solution and the need for consumption of electrode mass was less. ${ }^{8}$ Thus, by electrocoagulation process, the discharge of the treated wastewater to the other water bodies or environment can be performed safely. ${ }^{27}$

\section{Effect of pH}

Different hydroxide species formed during electrocoagulation are affected by $\mathrm{pH}$. The surface charge of the particles can also be modified by a change in $\mathrm{pH}$. Hydroxyaluminum species are generated on the hydrolysis of $\mathrm{Al}^{3+}$ ions. Predomination of aqueous complex $\mathrm{Al}\left(\mathrm{H}_{2} \mathrm{O}\right)_{6}{ }^{3+}$ at $\mathrm{pH}<4$ is observed. While hydrolysis products $\mathrm{Al}(\mathrm{OH})^{2+}$ and $\mathrm{Al}(\mathrm{OH})_{2}{ }^{+}$ are formed between $\mathrm{pH} 5$ and 6 . The most prevalent specie between $\mathrm{pH} 5.2$ and 8.8 is $\mathrm{Al}(\mathrm{OH})_{3}$ and $\mathrm{Al}(\mathrm{OH})_{4}{ }^{-}$is only predominant specie above $\mathrm{pH} 9 .{ }^{11}$ The effect of $\mathrm{pH}$ on the removal of nickel, lead and cadmium was studied at different $\mathrm{pH}$ ranged from of $1-9$ using aluminum and iron

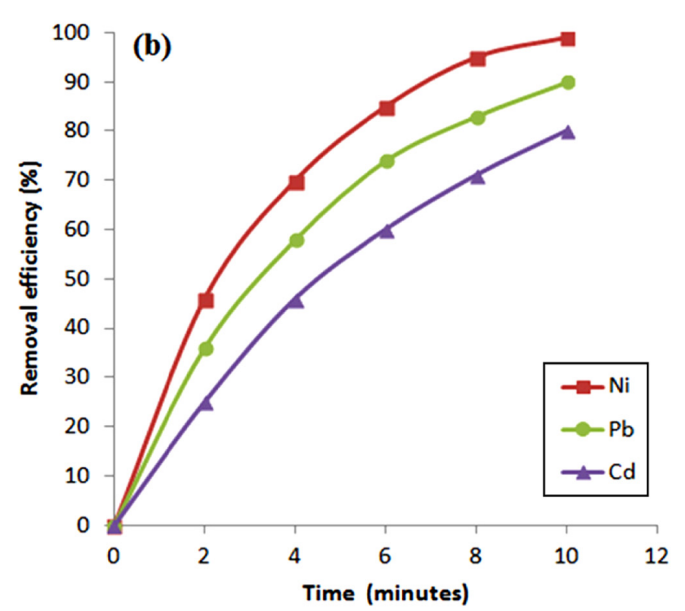

Figure 2. (a) Effect of Contact Time on removal of metals by using Aluminium electrodes (b) Effect of Contact Time on removal of metals by using Iron electrodes. 

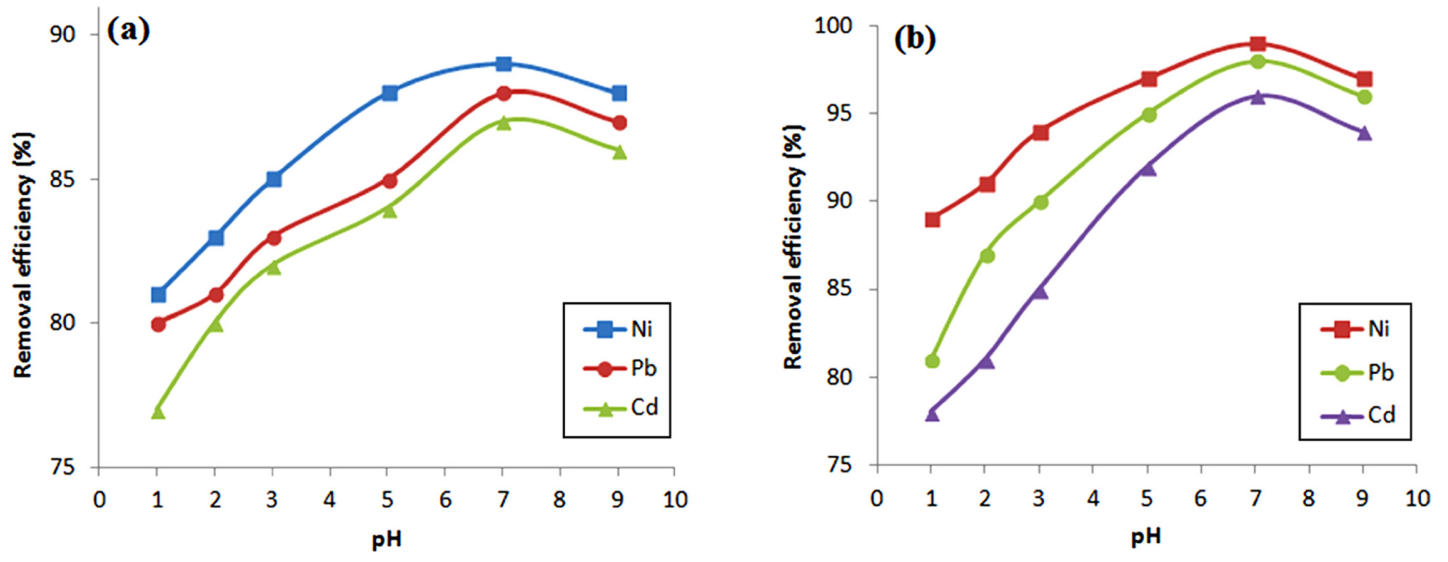

Figure 3. (a) Effect of $\mathrm{pH}$ on removal of metals by using Aluminium electrodes (b) Effect of $\mathrm{pH}$ on removal of metals by using Iron electrodes.

electrodes separately. The percent removal efficiencies of different metals as a function of $\mathrm{pH}$ presented in Fig. 3(a and $\mathrm{b}$ ). The maximum removal efficiency observed at $\mathrm{pH} 7$ for nickel which is about $87.8 \%$. In case of lead and cadmium, the percent removal efficiency is 88.2 and $87.9 \%$ respectively. Similarly, at optimized time and $\mathrm{pH}$, the maximum removal efficiency of nickel is $97.5 \%$ for iron electrode and removal of lead is 96.1 and cadmium removal is $94.8 \%$. As discussed earlier, the process of electro-coagulation can act as $\mathrm{pH}$ buffer for the treatment of wastewater so the additional cost for adjusting the $\mathrm{pH}$ of solution can be avoided during treatment. ${ }^{28}$

\section{Effect of Electro-coagulant Doze}

The conductivity of wastewater can influence the elec-

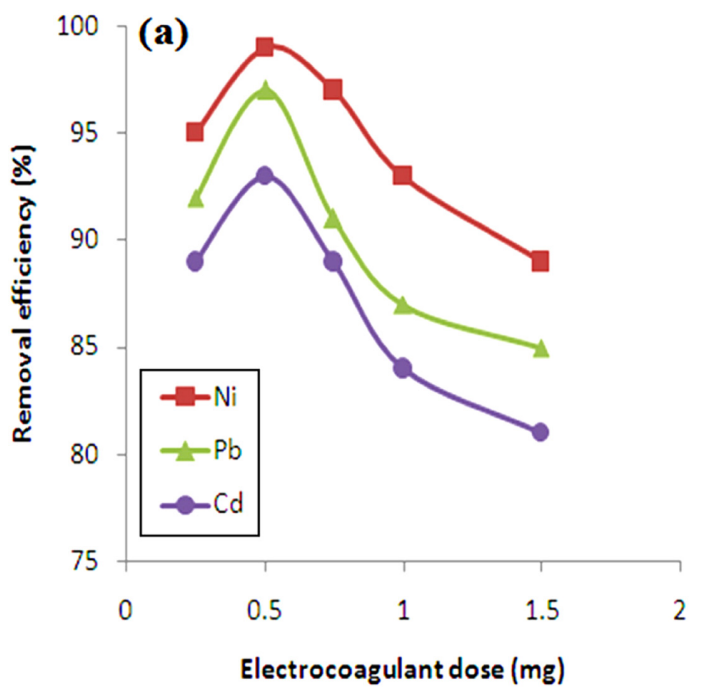

trochemical treatment because it facilitates the passage of current. To investigate the effect of the supporting electrolyte concentration on removal efficiency of nickel, lead and cadmium for aluminum and iron electrodes, different concentration of sodium sulphate $\left(\mathrm{Na}_{2} \mathrm{SO}_{4}\right)$ were added to the electrolytic cell respectively. There is a direct relation between concentration of electrolyte and conductivity of solution. As the $\mathrm{Na}_{2} \mathrm{SO}_{4}$ concentration increases, the conductivity of the solution increases. The metal ion removal efficiency decreases from for $0.25 \mathrm{M}$ to $0.125 \mathrm{M} \mathrm{Na}_{2} \mathrm{SO}_{4}$, because as the concentration increased the removal efficiency decreases. The maximum removal efficiency of different metals observed with $0.25 \mathrm{M} \mathrm{Na}_{2} \mathrm{SO}_{4}{ }^{2-}$ which is 95.5\% in case of nickel as shown in Fig. 7 and 91.1\% for lead and 93.2\% for cadmium as presented in Fig. 4(a and b)

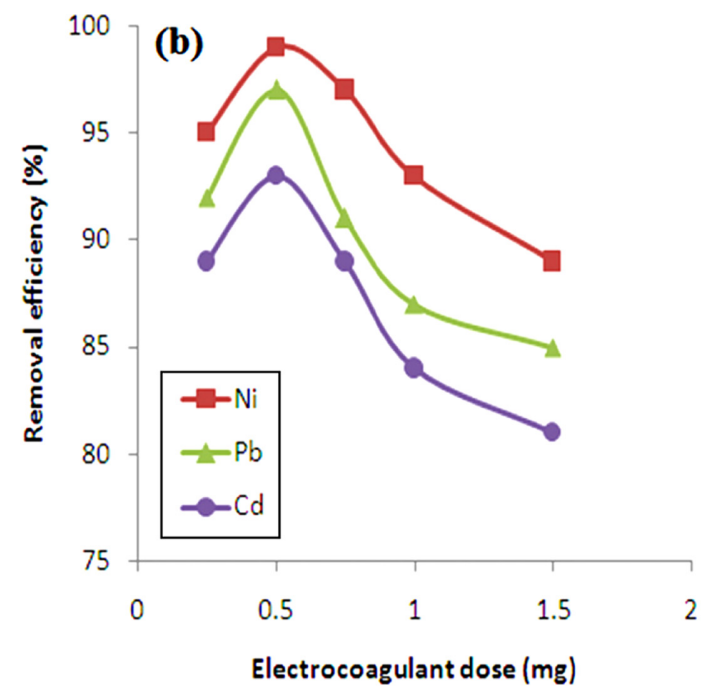

Figure 4. (a) Effect of electrocoagulant dose on removal of metals by using Iron electrodes (b) Effect of electrocoagulant dose on removal of metals by using Iron electrodes. 
by using aluminum electrodes. While by using iron electrodes, the removal efficiency of nickel is $99.6 \%$, lead removal is $99.7 \%$ and $98 \%$ cadmium removed. The reduction in metal ions removal efficiency with increasing supporting electrolyte concentration from $0.25 \mathrm{M}$ to $1.25 \mathrm{M}$ may be due to the excess of $\mathrm{SO}_{4}{ }^{2-}$ ions, which interact with hydroxyl ions and hindered the corrosion of aluminum and iron electrodes. ${ }^{29}$

\section{Effect of Current Density}

To determine the effect of applied voltage on the removal efficiency of nickel, lead and cadmium, Laboratory testing of the electrolysis cell involved. It is illustrious that the flocs growth, bubble production size and rate and coagulant dosage rate is determined by electrical current which can directly affect the treatment efficiency of the process of electrocoagulation. ${ }^{30-32}$ Consequently, it was investigated that the applied voltage has direct effect on the pollutants removal. As expected, the removal efficiency of metals increased by increasing applied voltage for a given period of time. At highest electrical voltage $(12 \mathrm{~V})$, quickest reduction of metal ions occurred and the maximum removal efficiency of nickel is $92.3 \%$ while that of lead and cadmium is 91.5 and $89.4 \%$ respectively by using aluminum electrodes as represented in the Fig. 5( $\mathrm{a}$ and $\mathrm{b})$. While by using iron electrodes, the maximum removal efficiency is $99.0 \%$ for nickel, $98.3 \%$ for lead and $96.8 \%$ for cadmium. Iron electrodes gives highest removal efficiency values as compared to aluminum. The lowest metal removal efficiency occurred in the lowest applied voltage $(5 \mathrm{~V})$. This is attributed to the fact that the amount of oxidized metal ions increased at higher voltage which favore the removal of the pollutants by forming greater amount of precipitates. It was observed that by

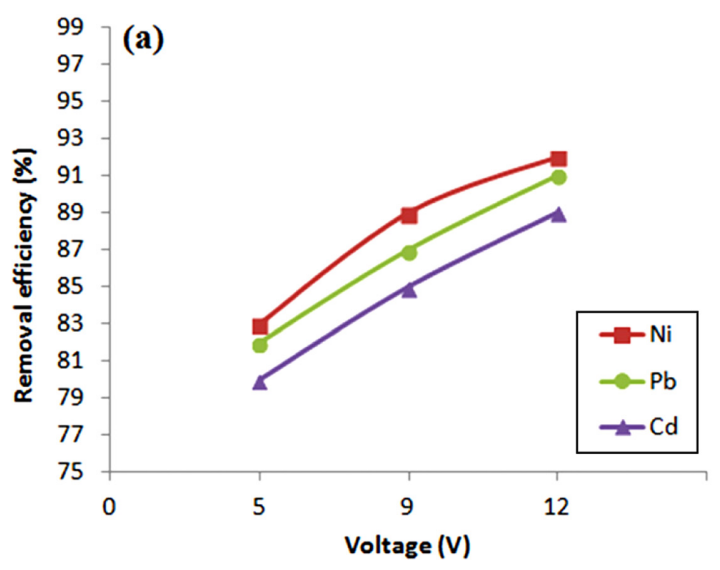

Figure 5. (a) Effect of Current density on removal of metals by using Aluminium electrodes (b) Effect of Current density on removal of metals by using Iron electrodes.

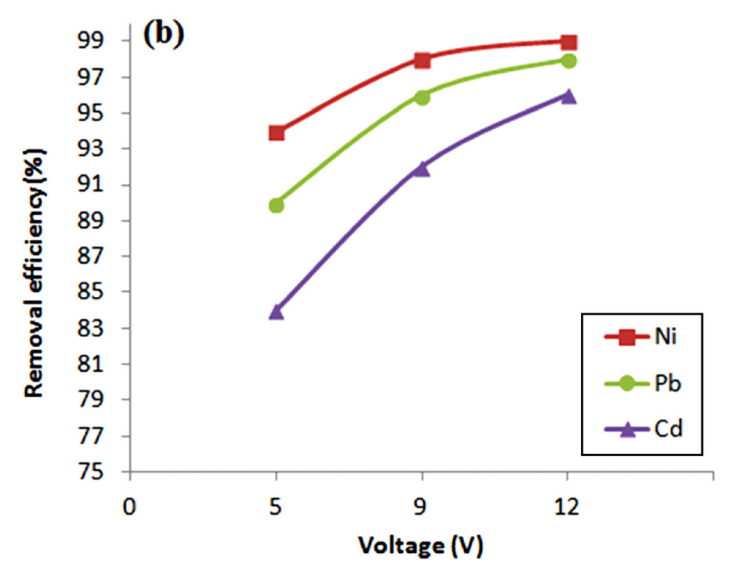

increasing current density, the size of the bubbles decreased and their density increased which in turn resulting in a faster removal of metal ions and greater upwards flux. ${ }^{33}$ The treatment efficiency of metal ions was mainly affected by charge loading phenomenon $(\mathrm{Q}=\mathrm{It}){ }^{34}$

\section{CONCLUSION}

Electrocoagulation (EC) is most efficient and cost-effective treatment method that has been applied for the treatment of industrial and synthetic wastewater.

A set of experiments was conducted in order to find the effects of different operational parameters on the removal efficiency of heavy metals and it was found that as the contact time increased, the percent removal also increased and high percent removal of metals by using aluminum and iron electrodes achieved at $\mathrm{pH}$ of 7 as the treatment efficiency was very poor either at low or high $\mathrm{pH}$. Different concentrations of $\mathrm{Na}_{2} \mathrm{SO}_{4}$ were used to increase the ionic conductivity of the wastewater. It was revealed that the percent removal of metals decreased at higher concentration of $\mathrm{Na}_{2} \mathrm{SO}_{4}$. While in case of current density, it has been observed that by increasing current density, removal efficiencies increased for both aluminum and iron electrodes.

Higher efficiency is obtained by applying $12 \mathrm{~V}$. The experimental results showed that iron electrodes are more efficient than iron electrodes. It may be because of high adsorption capacity of hydrous ferric oxides. Iron electrodes gives highest removal efficiency values $97.6,99.3$, and $98.8 \%$ for nickel, lead and cadmium as compared to aluminum $89.3,89.5$, and $91.4 \%$ at optimized parameters as discussed above. Journal of the Korean Chemical Society 
Acknowledgments. The authors thank the Higher Education Commission, Islamabad, Pakistan for financial support. (Grant No. 20-1434/R\&D/09/9057) And the publication cost of this paper was supported by the Korean Chemical Society.

\section{REFERENCES}

1. Kim, T. Y.; Park, S. K.; Cho, S. Y.; Kim, H. B.; Kang, Y.; Kim, S. D.; Kim, S. J. Korean J. Chem. Eng. 2005, 22, 91.

2. Choi, D. W.; Kim, Y. H. Korean J. Chem. Eng. 2005, 22, 894.

3. Stuart, F. E. Water Sewage 1946, 84, 24.

4. Chen, G. Sep. Purif. Technol. 2004, 38, 11.

5. Chen, X.; Chen, G.; Yue, P. L. Sep. Purif. Technol. 2000, $19(1-2), 65$.

6. Nikolaev, N. V.; Kozlovsii, A. S.; Utkin, I. I. Soviet J. Water Chem. Technol. 1983, 4(3), 70.

7. Musquere, P.; Ellingsen, F. Water Supply 1983, 1(2/3), 1.

8. Vik, E. A.; Carlson, D. A.; Eikum, A. S.; Gjessing, E. T. Water Res. 1984, 18(11), 1355.

9. Ciorba, G. A.; Radovan, C.; Vlaicu, I.; Masu, S. J. Appl. Electrochem. 2002, 32, 561.

10. Pulido, M. E.; Lamotta, E. J.; Nandipati, R. M. J. J. Ship Production 2001, 17(4), 191.

11. Jiang, J. Q.; Graham, N.; Andre, C.; Kelsall, G. H.; Brandon, N. P.; Chipps, M. J. Water Supply 2002, 2(1), 289.

12. Holt, P. K.; Barton, G. W.; Wark, M.; Mitchell, C. A. Colloids Surf., A 2002, 211(2-3), 233.

13. Han, M.; Kwon, A. Water Supply 2002, 2(5-6), 73.

14. Abuzaid, N. S.; Bukhari, A. A.; Hamouz, Z. M. Adv. Environ. Res. 2002, 6(3), 325.

15. Gurses, A.; Yalcin, M.; Dogar, C. Waste Manage. 2002, 22(5), 491.

16. Daneshvar, N.; Sorkhabi, A. H.; Kasiri, M. B. J. Hazard. Mater. 2004, 112(1-2), 55.
17. Mollah, M. Y. A.; Morkovsky, P.; Gomes, J. A. G.; Kesmez, M.; Parga, J.; Cocke, D. L. J. Hazard. Mater. 2004, 114(1-3), 199.

18. Fan, L.; Yang, F.; Yang, W. Sep. Purif. Technol. 2004, 34, 89.

19. Den, W.; Huang, C. Colloids Surf., A. 2005, 254(1-3), 81.

20. Pouet, M. F.; Grasmick, A. Water Sci. Technol. 1995, 31 (3-4), 275.

21. Pouet, M. F.; Persin, F. Water Sci. Technol. 1992, 25(12), 247.

22. Kumar, P. R.; Chaudhary, S.; Khilar, K.; Mahajan, C. Chemosphere 2004, 55, 1245.

23. Khemis, M. C.; Leclerc, J. P.; Lapicque, F. Chem. Eng. Sci. 2006, 61, 1237.

24. Daneshvar, N.; Oladegaragoze, A.; Djafarzadeh, N. J. Hazard. Mater. 2006, 129, 116.

25. Mahvi, S.; Naseri, A. R.; Mesdaghinia, C. Turkish J. Eng. Environ. Sci. 2008, 32, 59.

26. Apha, Wef. Standard Method for the Examination of Water and Wastewater, 18th ed.; AWWA: U.S., 1992.

27. Nouri, J.; Mahvi, A. H.; Bazrafshan, E. Int. J. Env. Res. 2010, 4, 201.

28. Vik, E. A.; Carlson, D. A.; Eikum, A. S.; Gjessing, E. T. Water Research 1984, 18, 1355.

29. Chen, X.; Chen, G.; Po, L.Y. J. Purif. Technol. 2000, 9, 65.

30. Tezcan, A. S.; Koparal, B.; Ogutveren, V. J. Environmental Management 2009, 90, 428.

31. Letterman, R. D.; Amirtharajah, A.; Omelia, C. R. $A$ Handbook of Community Water Supplies, 5th ed.; AWWA, Mc Graw-Hill: New York, U.S., 1999.

32. Holt, P. H.; Barton, G. W.; Wark, M.; Mitchell, A. A. Physicochemical Engineering Aspects 2002, 211, 233.

33. Karbassi, I.; Alaton, A. I.; Sahin, Y. The Open Environmental and Biological Monitoring Journal 2008, 1, 1.

34. Khosla, N. K.; Venkachalam, S.; Sonrasundaram, P. J. Appl. Electrochem. 1991, 21, 986. 